\title{
SOCIAL ENTREPRENEURSHIP AS A SUPPORTING MODEL FOR SUSTAINABLE RURAL DEVELOPMENT: A CASE STUDY OF CENTRAL LIKA (CROATIA)
}

\author{
Anita Bušljeta Tonković, Jelena Puđak and Dražen Šimleša
}

\author{
Institute of Social Sciences Ivo Pilar \\ Regional centre Gospić \\ Trg Stjepana Radića 4/1, 53000 Gospić \\ e-mail: anita.busljeta.tonkovic@pilar.hr
}

\begin{abstract}
The main goal of this paper is to explore social entrepreneurship as a supporting model for sustainable rural development that could bring the developmental facets of the Lika Region into balance. The theoretical concepts used are related to the representation of the connection between neo-endogenous and sustainable development. The paper consists of two parts: in the first part, the results of desk research are presented, which describe the social entrepreneurship scene in Croatia; in the second part, the results of the two-stage qualitative research are given. The first stage consisted of semi-structured interviews with local social actors involved in Lika's current socio-economic development (2013), with the emphasis on the economic dimension of sustainable development. The second stage consisted of semi-structured group interviews with social entrepreneurship practitioners in Lika (2015), namely civil society organizations, with the emphasis on the status and developmental level of social entrepreneurship. The results show that social actors are aware of the opportunities for sustainable development in Lika (e.g. preserved natural resources), as well as of alternative and I or complementary economic models that could foster an enhanced quality of life. Key social actors (research participants) see social entrepreneurship as an opportunity to develop an alternative / complementary economic model in Lika, e.g. "to incorporate people's ideas into the economy and to adapt the economy to the people". An additional push factor for the development of social entrepreneurship is connected to third-sector actors who are developing a new project: eco-social farms and grouping of farms based on inventiveness, communality and social capital.
\end{abstract}

Keywords: civil society, local social actors, social entrepreneurship, sustainable development

\section{INTRODUCTION}

Social entrepreneurship, as one of the forms of social economy, is far from being a novelty in the European socioeconomic context. The contemporary development of social entrepreneurship is based on the past century of experience by cooperatives, foundations, mutual-aid societies and similar organizations that have all been characterized by the synergy of solidarity, social equality and economics. The development of social en- 
trepreneurship in Europe has been quite closely linked to efforts aimed at achieving the general well-being of local communities. The first cooperatives and mutual aid societies were established in the early $19^{\text {th }}$ century, whereby the "silent stage" of social entrepreneurship ended in the 1970s, when the welfare state began to weaken and neo-liberal capitalism became stronger (Ridley-Duff and Bull, 2013; Šimleša et al., 2015b). During the first decade of the $21^{\text {st }}$ century, social entrepreneurship has taken the form of a global phenomenon with a sort of discernable social change at its focus. It is a new paradigm that offers solutions to numerous market failures, one oriented toward meeting social and environmental needs, such as environmental crises or growing economic inequality (Drayton, 2002; Volkmann et al., 2012; Šimleša et al., 2016).

The characteristics of the key actors of social entrepreneurship in the early $21^{\text {st }}$ century can be summarized as pragmatism, innovation and a specific vision. These actors created their vision based on a combination of elements from the business world, charities and social movements, thus managing to form new and sustainable social values (Nicholls and Cho, 2006). Their activities contributed to social change which reflected the relationships between action and structure within a single segment of socioeconomic development (Steinerowski et al., 2008).

Social entrepreneurship in Croatia has been growing intensively since 2000. The first scholarly research project that collected the basic data on the status of social entrepreneurship was launched in $2013 .^{1}$ The preliminary results collected through the project showed that the base of Croatias social entrepreneurship actors consisted of 90 legal entities in 2014 and included organizations, cooperatives, companies and institutions (Šimleša et al., 2015a; Šimleša et al., 2016).

When the data gathered on the number of actors in Croatia is presented on the basis of territory, i.e. shown in the counties in which they operate, it can be concluded that two (out of 20) counties, namely Split-Dalmatia and Osijek-Baranja, account for over one third of all those registered. The alarming fact is that there are less than three social entrepreneurship actors in each of over one half of the counties, including Lika-Senj County, while there is not a single actor in six counties. ${ }^{2}$ The organizations involved in social entrepreneurship (i.e. a total of 90 in 2014) had 795 employees. The number of

\footnotetext{
1 iPRESENT (Installation Project for REsearch about Social ENTrepreneurship), project code 5332. This is a research project financed by the Croatian Science Foundation. The project's central objective is to research the capacity and potential of social entrepreneurship as an environmentally responsible and socially sensitive business model in Croatia.

2 According to territorial structure, the Republic of Croatia has 21 counties, including the City of Zagreb, which has the status of a county. According to this structure, the distribution of social entrepreneurship actors is as follows: 17 in Split-Dalmatia County, 14 in Osijek-Baranja County, 10 in the City of Zagreb, 9 in Istria County, 8 in Međimurje County, 6 in Dubrovnik-Neretva County, 6 in Bjelovar-Bilogora County, 6 in Šibenik-Knin County, 4 in Primorje-Gorski Kotar County, 3 in Varaždin County, 2 in KoprivnicaKriževci County, 2 in Sisak-Moslavina County, 1 in Brod-Posavina County, 1 in Lika-Senj County, 1 in Zagreb County, and 0 (none) in Karlovac, Krapina-Zagorje, Požega-Slavonija, Virovitica-Podravina, VukovarSrijem, and Zadar Counties (90 in all). For more research results, please consult Šimleša et al., 2015a, 2016.
} 
employees varies depending on the needs of a specific organization, or on the market demand for their products and services (Šimleša et al., 2015a; Šimleša et al., 2016). The paper presents the growth potential for social economy or social entrepreneurship in a specific rural area: Lika-Senj County, the traditional region of Lika and the central Lika sub-region in particular, which belong to Croatia's mountain zone. This zone lies at the intersection of the Mediterranean, Pannonian and Dinaric sections of the country (Rogić, 1977; Pejnović, 2009; Magaš, 2015). Lika-Senj County, territorially the largest county in Croatia, is located in the country's rural zone. The county is known for its rich and protected natural resources $(58 \%$ of all protected natural areas in the state are located in the county). It is the least populated (population: 50,927, Croatian Bureau of Statistics, 2011) and the least densely populated (9.6 inhabitants per square kilometer) Croatian county. The urban / rural ratio is on the side of urban population which accounts for $55 \%$, while the rural population is $45 \%$. Modernization processes have had little impact on the county, leaving it with clean natural resources (water, air, soil) which can be perceived as an advantage and an opportunity for careful planning and implementation of contemporary developmental concepts. The county encompasses four towns and eight municipalities. The town of Gospić (population: 12,745, Croatian Bureau of Statistics, 2011) is the county seat, its largest town and the center of the traditional Lika Region and central Lika.

We will be considering the traditional Lika Region and its sub-regions within the context of territorial approach, since this approach has become important, in particular for emphasizing the functionality of a region rather than its political orientation. ${ }^{3}$ This constitutes an attempt to better comprehend the complex dynamics of economic relations within the region, as well as the relationship between the region with the rest of the country and / or Europe (Woods, 2012). The region's geographic location is shown in figure 1. (p. 4)

\section{THEORETICAL CONCEPTS AND RESEARCH PURPOSE}

A rural area will be defined according to its four essential elements: rurality, agriculture, environment and technology. These elements are in turn defined by four dimensions: socio-cultural, developmental, economic, and environmental. The socio-cultural dimension encompasses folk culture, customs and traditions. The developmental dimension rests upon and is achieved through the use of overall and specific natural resources in a particular rural area. The economic dimension is directly tied to development and signifies the well conceived and planned utilization and also restoration of existing resources, be they natural, human or social. Finally, there is the environmental dimension of rurality that denotes an ecological approach to the overall production of goods and ser-

3 In the sense of a traditional region, Lika consists of five sub-regions: central Lika, Gacka field, Krbava field, southern Lika and Una River valley of Lika (Pejnović, 2009). 


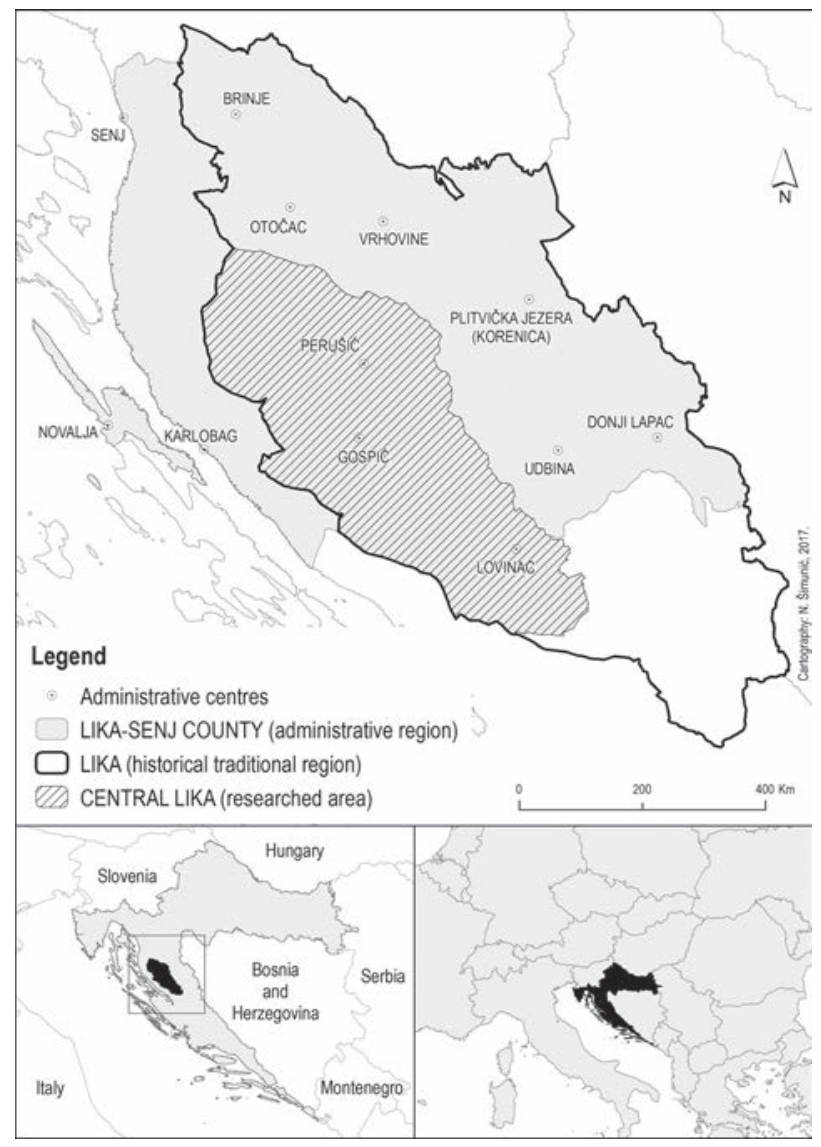

Figure 1. Map of the region encompassed by the study, Lika-Senj County, the Lika Region and Central Lika

vices and, in particular, the preservation of biodiversity. Technology, meaning modern scientific and technological achievements, should be understood here as a framework that contributes to the preservation and sustainable use of natural resources and the quality of life of local communities. These four dimensions define a rural area as a whole of indivisible parts: agriculture, technological system and natural environment, which together form the rural landscape and countryside (Cifrić, 2003; Sundalić, 2010).

Such a concept of a rural area, including the local communities living therein, should be approached as part of the sustainability concept. ${ }^{4}$ Social development, along with traditional views as the "type of social changes that lead to an increase in the quantity

4 A local community can most easily be defined as a group of people whose day-to-day life, whether jobrelated or not, is tied to a certain geographic area (Abercrombie et al., 2008). Thus, a local community is defined geographically, tied to a specific location, i.e. indicating a community of place. This means that a 
and quality of material and spiritual assets, improved spiritual relations and an overall improvement in the quality of human life, human rights and freedoms" (Fiamengo, 1987; Bušljeta Tonković, 2015a:17), began to be more seriously considered within the context of care for the environment and its protection in the latter half of the $20^{\text {th }}$ century. Under the sustainable development concept, the natural environment is viewed as the fundamental prerequisite for the long-term survival of both the local community and society in general. Sustainable (rural) development, as defined within the context of a rural area, encompasses the economic, social and cultural growth of a certain rural area and the community living therein, which, naturally, includes the preservation and development of the natural environment. Such development is based on the optimization of all components of the area in question, rather than on maximizing success based solely on generating profit. Optimization, in turn, pertains to sustainable and planned use and enhancement of natural, human and produced resources (Defilipis 1993; Bušljeta Tonković, 2015a:195). One of the basic precepts for achieving sustainable (rural) development is the synergy between human and social capital (Sen, 1999; Putnam, 2001; Evans, 2001). Given the four above-mentioned dimensions that define a rural area in greater detail, it is noteworthy that the four basic dimensions of sustainable development consist of environmental, socio-cultural, economic and political dimensions (Redclift, 1991; Lay, 2007). ${ }^{5}$ These can easily be tied to the dimensions of rural space. This paper does not allow for a thorough discussion of human and social capital. However, it can be briefly presented, i.e. included in the presentation of the neo-endogenous developmental concept. This concept emerged recently and is based on the fundamental idea that local developmental factors should be recognized and acknowledged as the initial platform for the creation of a sustainable future (Ray, 2001; Tolon-Becerra et al., 2010). The underlying postulate of this concept is the validation of a particular rural area and local communities as the major actors in the formation and improvement of overall socioeconomic conditions. The neo-endogenous concept takes human and social capital as the key segments of a community. The balance between the bottom-up and top-down approaches may be this concept's most desirable feature. In the neo-endogenous developmental concept, local initiatives constitute a segment that can formulate an ad hoc concept of a particular developmental project (activity) based primarily on personal experience as well as vision and wants. The moment representing the final decision is the point at which the bottom-up and top-down approaches meet (Ray, 2001; Tolon-Becerra et al., 2010; Atterton et al., 2011).

local community shares an area, possesses certain values, experiences and interests, as well as distinct local knowledge. Stated briefly, a local community is one in which territorial affiliation is the main territorial principle and means of mutual identification (Geiger Zeman and Zeman, 2010).

5 Generally, there are three basic dimensions of sustainable development, as confirmed by the recent report by the United Nations General Assembly Economic and Social Council (2016), where the economic, social and environmental dimensions were once again emphasized. For the purposes of this paper, a fourth dimension of sustainable development has been included, the political dimension, even though the paper concentrates on the economic dimension and its role in accomplishing balanced development. 
The social economy in general, including social entrepreneurship, contributes to added social value primarily through enhanced social cohesion, employment, creation and maintenance of social and economic structure, development of democracy, social innovation and local development (Connelly et al., 2011). This type of economy also drives the developmental potential of rural areas, which account for about $90 \%$ of Croatia's total territory, thus bringing balance to territorial imbalances. ${ }^{6}$ In light of the authentic logic of distribution of profit and surplus, according to which the social economy promotes the impact of spreading endogenous economic growth (development on the local level and accumulation processes) and minimizes the effects of a decline in such development, it contributes, among other things, to a re-investment of profits in the area in which they were earned, mobilizes local actors who best know their own environment and resources at the local level, and leads to the creation of social capital (Chaves and Manzón Campos, 2010).

Here it should be noted that social entrepreneurship essentially bears three basic elements: creation of social values, innovation-oriented activities (the creation of something new), and reliance on business mechanisms and, at least partially, the market (Baturina, 2013, as cited in Šimleša et al., 2016:275). The concept of sustainable development strives to optimize all components in a given area, i.e. puts emphasis on the sustainable, planned use and enhancement of natural, human and produced resources (Defilipis, 1993; Bušljeta Tonković, 2015a). Keeping this in mind, social entrepreneurship in its essence contains the strong social component typical of the third sector, but also a component inherent in the private sector, i.e. entrepreneurial skills. The main goal of the combining of these components is to strengthen or create sustainable local communities (Steinerowski and Steinerowska-Streb, 2012). The neo-endogenous developmental concept is, according to its basic definition, complementary to the other two concepts. In that sense, it actually marks the point where the bottom-up and top-down approaches meet. The desired result of combining the above stated concepts is the general level of sustainability in all given dimensions - economic, socio-cultural, environmental, and political. The use and combination of these concepts, tested in practice elsewhere in Europe and analyzed and verified by experts (Navarro et al., 2016), facilitate the selection of the best solutions.

The Croatian "Strategy for the Development of Social Entrepreneurship" (2015:7) defines social entrepreneurship as "business based on the principles of social, environmental and economic sustainability, whereby the profit made / extra income is entirely or in part invested in the welfare of the community". The given definition, as grounds for discussion in this paper, allows for a further analysis of its main concepts. Social entrepreneurship can be recognized as a supporting model for sustainable rural development, primarily in its economic and thereby socio-cultural, environmental and political dimensions. In the economic dimension, it represents a support model for strengthening the local community, whereby generated profit is returned or re-invested to strengthen the community's

6 Data source on the rural areas of the Republic of Croatia: Strategy for Rural Development of the Republic of Croatia 2008-2013 (Ministry of Agriculture, Fishery and Rural Development, 2008). 
financial status and infrastructure. In the socio-cultural dimension, the aforementioned re-investment signifies the strengthening of local communities in the form of investment in human (knowledge, skills and health) and social (trust, reciprocity norms and linked networks) capital. In the environmental dimension, social entrepreneurship represents sustainable use and, quite importantly, the use rather than exploitation of local natural resources. Taking into consideration the principles of social, environmental and economic sustainability, social entrepreneurship additionally rests on democratic decision-making principles, thus influencing the political dimension of sustainability.

The use of these concepts and consideration of their interaction place this paper in the contemporary theoretical discourse on the methodological framework of post-positivist disciplines while favoring structuration theory (Giddens, 1999; Giddens 2007; Steinerowski and Steinerowska-Streb, 2012). It is the economic dimension of rurality together with the economic dimension of sustainable development that forms the core of the topic to be presented below. In this context, the main purpose of the article - to explore social entrepreneurship as a supporting model for sustainable rural development that could bring the developmental facets of the Lika Region into balance - will be achieved by presenting the research results and also considering two research questions. These questions are discussed through: a) deliberation of social entrepreneurship as a supporting model for sustainable rural development in general, and through b) deliberation of the possibilities for balancing sustainable development via social entrepreneurship concretely in the Lika Region rural area.

\section{RESEARCH INSTRUMENTS, DATA COLLECTION AND PROCESSING}

Qualitative research methods form the backbone of this paper. First, the qualitative research (semi-structured interviews) was conducted in the area of Central Lika during the course of 2013. The data presents the general situation of sustainable development and possibilities in the Lika sub-region with some emphasis on its economic dimension. The data gathered in 2013 was partially released in two publications; however, data related to the economic dimension of sustainable development, specifically the potential for the development of alternative and complementary economic forms, remained outside the focus in previous publications. ${ }^{7}$ In short, this qualitative research (2013) helped establish the possibilities for sustainable development in central Lika. ${ }^{8}$ As already men-

7 For details on data gathering, sampling and analysis from the 2013 research, see Bušljeta Tonković, 2015a:219-221; 2015b:168-171.

$8 \mathrm{~A}$ brief explanation is necessary to shed light on the reasons why the research was conducted in the territory of central Lika, and not the entire territory of the Lika Region and Lika-Senj County. The primary reason pertains not only to the central geographic location of central Lika in Lika-Senj County, but also to its administrative position. With the town of Gospić, the only town in the sub-region and the county seat, central Lika stands out as it has the largest concentration of institutions, college-educated population and economic activities. That makes the sub-region simply an ideal testing site for the research. 
tioned, one of the research topics was the economic dimension of sustainable development. The field research sampling was intentional and encompassed relevant actors from the public and private sectors. The sampling was supported by the snowball technique first, a small group of experts, farmers and entrepreneurs was selected, whose suggestions helped expand the sample by pointing out potential persons who might be interviewed. This sampling method was used as it was imperative to include specific categories of interviewees, whose expertise and knowledge could provide concrete answers related to all four dimensions of sustainable development. There were 29 participants involved in the semi-structured interviews. These participants were local social actors involved in social and economic realities with specific knowledge of the local area: employees in state institutions and the media (highly positioned representatives in the state, county or municipal institutions, representatives of the local media, actors from the educational system, employees of nature protection institutions), and the self-employed (entrepreneurs, sole traders, family farm owners). The initial analytical strategy of the data analysis had five stages. ${ }^{9}$ The Thematic analysis method used for processing interviews was conducted with the Atlas.ti computer program (multilevel open coding). The main purpose of this data gathering and analysis was in key actors identifying the: 1) development possibilities for alternative and complementary economic forms; 2) desirable forms of alternative and complementary economies according to social actors; and 3) potential for alternative and complementary economies, i.e. social entrepreneurship.

The paper also presents the results of the qualitative research (semi-structured group interview) that was conducted during the course of 2015. The data presents the standpoint of local actors on the general situation of social entrepreneurship and its development potentials in the Lika Region. The second qualitative research (2015) helped establish the perspectives for social entrepreneurship. A group interview was conducted with a social entrepreneurship actor in Lika, the non-governmental organization Prospero, in May 2015. ${ }^{10}$ One of the interview topics was the development and implementation of social entrepreneurship in the Lika Region. ${ }^{11}$ The sample included actors from the base of social entrepreneurship in Croatia, taking into account their territorial distribution (Šimleša et al., 2015a)..$^{12}$ There were 10 participants with first-hand experience about social entre-

\footnotetext{
9 For the initial analytical strategy, see Schmidt, 2004 and Bušljeta Tonković, 2015 b:171.

10 As the organization Prospero is the sole social entrepreneurship actor in Lika, this made it difficult to keep its name anonymous. The organization's members, i.e. the interview participants, agreed to publication of the data, clearly showing the identity of the organization. Furthermore, the organization's members authorized the paper prior to publication.

11 The research was part of a more comprehensive research conducted for the needs of the iPRESENT project, with publication of the results still pending.

12 Social entrepreneurship business and legal entities have not been legally regulated in Croatia as yet (there is no legal form of social entrepreneurship), thus only actors meeting the following criteria were selected for the base: media presence, scholarly papers and / or public profile with a clear reputation as an actor implementing social entrepreneurship; implementation of projects or establishment of legal entities that engage in social entrepreneurship; inclusion on any of the existing lists of social entrepreneurs. As a minimum for
} 
preneurship in the county involved in the semi-structured group interview. The research participants were female members of the organization Prospero, which carries out social entrepreneurship projects. The participants hold leading positions in the organization namely as president, vice president, secretary and educators. The educators work with socially vulnerable groups and socially excluded persons (e.g. unemployed women, youth and disabled). The Thematic analysis method was once again used for processing interviews, conducted with the Atlas.ti computer program (multilevel open coding). This data gathering and analysis aimed at actors identifying: 1 ) the general approach of the organization to social entrepreneurship; 2) the approach of the organization to the social entrepreneurship scene in Croatia and the Strategy for Social Entrepreneurship; 3) self-assessment of the role and position of the organization on the national level; and 4) self-assessment of the role and position at the county level.

The gathered data also clearly indicates the status of social entrepreneurship in rural areas. Lika-Senj County stood out as a particular case in which there is only a single civil society organization that shows potential for the development of social entrepreneurship. Social actors and their perception on shaping the economic dimension of sustainable development as ascertained by the 2013 research in comparison to the research from the iPRESENT project (2015) indicated the existence of certain common points and the possibility of making a basic comparison. The comparison of the two research projects indicated a moment that could be characterized as the foundation for shaping the possibility of developing social entrepreneurship in the form of a support model for sustainable development.

\section{RESEARCH RESULTS}

We will first analyze the data gathered in the 2013 research also presented in Tables 1 and 2. To obtain a picture of sustainable development as seen by the region's key actors, we asked the interviewees for their views on the current situation and prospects for future (sustainable) economic development. The interviewees believed that the lower level of overall socioeconomic development in Lika resulted from a general dearth of knowledge, expertise in particular, and a lack of ideas and creativity. Even though they did not see unemployment as a pressing problem, they emphasized it would come to the fore in the next 10 years, as vacant posts (administrative, in particular) are lost. This was where interviewees saw the first chance to develop complementary and alternative economic forms. ${ }^{13}$

inclusion in the base, each legal entity had to meet all three criteria, and Prospero met all three criteria. For more information about Prospero, see https://www.udrugaprospero.org/wordpress/.

13 The interviewees defined the terms of "complementary and alternative economic forms" as those parts of the economy that either complement conventional economy (complementary economic forms, e.g. social entrepreneurship) or act contrary to the conventional economy (alternative economic forms, e.g. power generation from renewable sources owned by a local community). 
The interviewees saw tourism as underdeveloped and currently rather disorganized. Although they did not rank this particular industry first in the overall economic development, they emphasized it as a sound channel, primarily for placing local goods and services on the market. They also emphasized the preservation of natural resources, which constitutes a basic prerequisite for tourism development. This is where the interviewees see the second chance for the development of complementary and alternative economic forms. The latter is expressed as the combination of 'pristine nature', various actors from the private and public sectors (small farms, sports associations, local government and the religious community) and various specific types of tourism whereby both economic production and socio-cultural and environmental sustainability are achieved.

The interviewees also stated that agricultural production, which is directly linked to the preservation of resources, was not sufficiently developed. Agriculture can progress on small family farms; however, it mostly meets personal needs, with quantities insufficient for year-around consumption even on the farm itself. Such production does not contribute much to the household budget. Since families grow fruits and vegetables, and produce meat and dairy products for their own needs in a traditional manner, they mostly do not use pesticides and other chemical inputs, which certainly contributes to the environmental sustainability of local communities. According to the interviewees, this is the third chance for developing complementary and alternative economic forms that should be in synergy with the first two.

The aforementioned three opportunities for the development of complementary and alternative economic forms led the interviewees to the conclusions elaborated herein. Connections and cooperation between regional and local institutions are primarily needed to provide support for connections at the lower level, e.g. associations of family farms, formation of cooperatives and economic clusters. Expert knowledge might play a role here, in particular when it comes to applying for EU funds. The actors believed that local communities should profit from this. They are the first whose overall living conditions should improve. They also believed complementary economic forms such as social entrepreneurship are the key elements of development, in particular in food production and also in the utilization of natural resources in general, emphasizing the possibility of energy generation from alternative sources and the well-being arising from it for local communities. The actors see civil society as a vital element that could serve as an intermediary between the public and for-profit sectors. It should be noted that the role of civil society is even greater as it may provide additional stability for both sectors, because complementary and alternative economic forms were created at the national level within the domain of civil society. Thus, civil society possesses verifiable knowledge and experience that has been present on the social entrepreneurship scene for over a decade.

The interviewees also deemed that additional education of the local population will be necessary to form contemporary, sustainable and profitable economies at the local level. Expert educators must be "imported" as there are not enough of them in Lika. The knowledge to be shared with local communities needs to be adjusted to local con- 
texts. Learning from successful real-life examples is vitally important. The interviewees believed information (primarily new / contemporary knowledge and skills) was still "barely flowing" to Lika in that it takes more time to reach developmental actors. This can also be seen in the case of entrepreneurship as there are only a few actors that have introduced some form of innovation. However, those that accepted and implemented innovation (e.g. alternative forms of tourism, such as adventure tourism) survived and do business successfully. The interviewees also concluded that, due to insufficient information, there is a lack of opportunities for the development of contemporary economic forms in Lika. The economy remains unsuited to the needs of local communities in such a vacuum, and the interviewees were of the opinion that political structures that do not recognize the problem contribute to it by constantly and unsuccessfully attempting to empower conventional economic forms. An "economy of everything and anything" thus ensues in such a situation - an economy with no predetermined objectives, or strategy and direction.

The interviewees also expressed that local political structures should be the key facilitators of administrative and financial support in the initial launch of complementary and alternative economic forms in particular. They believed that one of the basic incentives for the local political scene to assume this role might be higher tax revenues, as by developing complementary and alternative economic forms, activities falling under the "gray economy" would decline. Repeatedly emphasizing the exceptional importance of establishing cooperation at all levels, the interviewees were of the view that such joint efforts would create a platform for improving general demographic trends in Lika. ${ }^{14}$ The first stage of accomplishing this entails completion of already initiated projects or planning new ones to build the required infrastructure - from roads and other utility infrastructure to infrastructure tied in to the improvement of educational institutions. Work habits, social responsibility and creativity are all areas requiring better results. This is not a matter of the negative traits of an individual, for the interviewees believe that the problem lies in the aforementioned lack of information, lack of experts, i.e. expert knowledge, examples of sound practices, in particular those with a complementary, rather than competitive, character, and information on entrepreneurship created in the western European cultural milieu.

Hence, strategic planning of economic development, along with the adoption of the contemporary economic models from the EU, in particular those that, like social entrepreneurship, can be easily adapted to smaller local communities, are seen by the interviewees as being crucial to balancing the economy dimension of sustainable development in this particular rural area.

14 We took the share of the county's population in the total national population as one of the basic indicators of negative demographic trends in Lika-Senj County. For example, in 1900 the share of Lika-Senj County's population in the total was $5.9 \%$; in 2001 it was $1.2 \%$, as it was in 2011 (Akrap and Gelo, 2009). For more on demographic trends in Lika, see Bušljeta Tonković, 2015a; Pokos and Turk, 2013; Akrap and Gelo 2009. 
Soc. ekol. Zagreb, Vol. 27 (2018.), No. 1

A. Bušljeta Tonković et al: ...Sustainable Rural Development: A Case Study of Central Lika (Croatia)

Table 1. Semi-structured interview results - interviewee opinions on the status of the economy

General interviewee conclusion: the lower degree of total economic development in Lika is a result of deficits in knowledge, expertise, ideas and creativity

\section{Interviewees standpoint on:}

(Un)employment - there is no particular problem with unemployment, but the problem will appear in the next 5 to 10 years.

Degree of development of tourism - undeveloped and disorganized.

The interviewees saw the future of tourism in Lika tied to its pristine and untamed environment and cultural attractions:

- adventure, alpine, hunting and sporting tourism (Mt. Velebit and Kapela)

- religious tourism (the area of Lika is a transit territory on the way to Međugorje; Lika has the Shrine of Krasno and a newly-built church in Udbina)

- health tourism - clean air and water

- rural tourism - organic foods, traditional house building and a preserved natural environment

Food production (family farms) - exists, but at a level insufficient to provide for an annual family budget

Organic farming - is seen as potential for economic and overall social development, keeping in mind untilled agricultural land and perceptions of local nature as preserved and uncontaminated.

Recommendations of interviewees for a (better) future:

- connections, mutual cooperation

- use of EU funds

- taking the opinions of experts into consideration

- "focused economy" - production of domestic products and organic food, production of energy from renewable resources, which includes the local community!

- bolstering civil society, which would could assume the role of "mediator"

Table 2. Semi-structured interview results - interviewee opinions on a modern, sustainable and profitable economy

\begin{tabular}{|l|l|l|}
\hline $\begin{array}{l}\text { Achieving a modern, sustainable } \\
\text { and profitable economy will } \\
\text { require: }\end{array}$ & $\begin{array}{l}\text { Obstacles to the achievement } \\
\text { of a modern, sustainable and } \\
\text { profitable economy are: }\end{array}$ & $\begin{array}{l}\text { Ideas for achieving a } \\
\text { modern, sustainable and } \\
\text { profitable economy }\end{array}$ \\
\hline $\begin{array}{l}\text { Education on new / } \\
\text { contemporary economic models } \\
\text { (expertise) }\end{array}$ & Lack of experts & $\begin{array}{l}\text { To assume contemporary } \\
\text { models from the EU } \\
\text { Strategic plan for } \\
\text { economic development } \\
\text { Fairer distribution } \\
\text { using new economic } \\
\text { forms à e.g. social } \\
\text { entrepreneurship }\end{array}$ \\
\hline
\end{tabular}




\begin{tabular}{|c|c|}
\hline $\begin{array}{l}\text { Learning from examples / practice } \\
\text { in other parts of Croatia and } \\
\text { especially in other EU member } \\
\text { states }\end{array}$ & $\begin{array}{l}\text { Lack of information about } \\
\text { all economic forms (lack } \\
\text { of alternative economic } \\
\text { opportunity) }\end{array}$ \\
\hline $\begin{array}{l}\text { Networking and cooperation } \\
\text { (mutual institutions and } \\
\text { cooperation with the civil sector) }\end{array}$ & $\begin{array}{l}\text { The current economy is } \\
\text { not adapted to the needs } \\
\text { and possibilities of the local } \\
\text { community } \\
\text { The political structure does } \\
\text { not recognize the potential of } \\
\text { new economies }\end{array}$ \\
\hline $\begin{array}{l}\text { Association and cooperation } \\
\text { to achieve new (alternative) } \\
\text { economic forms }\end{array}$ & $\begin{array}{l}\text { Economy of "doing } \\
\text { everything" }\end{array}$ \\
\hline $\begin{array}{l}\text { Better demographic picture } \\
\text { (missing youth) }\end{array}$ & \\
\hline $\begin{array}{l}\text { The basic infrastructure } \\
\text { Financial support }\end{array}$ & \\
\hline $\begin{array}{l}\text { Work habits } \\
\text { Creativity } \\
\text { Social responsibility } \\
\text { Complementary supply } \\
\text { Enterprising }\end{array}$ & \\
\hline
\end{tabular}

The data gathered during 2015, showing the status of social / business scene in the Lika Region, is presented in Table 3. As the only social entrepreneurship actor in Lika, the organization Prospero is focused on solving the problem of unemployment in marginalized social groups, primarily women, youth and persons with disabilities. In that respect, the organization operates in the field of human rights. It concentrates on employment and the economic empowerment of marginalized social groups through education and training. The economic branch on which it concentrates is agriculture, i.e. self-employment of women and youth in agricultural and traditional crafts. To that end, the organization established a women's social cooperative that has 40 members, 10 of whom are active and directly involved in everyday activities.

Table 3 clearly indicates commonalities in appraisals of the status of Lika, the obstacles to and possibilities for its development by the key actors (interviewees), and Prospero as the sole social entrepreneurship actor. The organization's members believe that the most significant features of the social entrepreneurship concept are innovativeness and the freedom to combine various economic models, whereby they emphasized the environmental dimension and environmental protection, the creation of social values that could not come to the fore due to the traditional patriarchal heritage, and enhancement 
of social capital through cooperation and education. They believe that social entrepreneurship is insufficiently developed at the national level, one of these being the status of civil society which is the main social entrepreneurship actor to which national, regional and local authorities still do not provide sufficient support and room for maneuver. They further hold that it is vital to create social capital through the organization's activities and the promotion of social entrepreneurship. They ranked community mobilization first, which the organization's members believe would foster mutual trust. Hence, the participants in the group interview, as well as the key actors interviewed in 2013, emphasized nature conservation as the fundamental potential for economic and social development and indicated the lack of understanding from and inertia by administrative structures as an obstacle, while seeing local communities and the civil sector as the drivers of (positive) change.

The organization primarily views agriculture as an opportunity for the development of social entrepreneurship in the Lika Region. They organized the first training of local communities on social entrepreneurship through the project "Eco-social development of the Velebit area: Work in progress!" thus presenting self-employment possibilities. The ultimate goal of the organization is the implementation of a prepared pilot-project that would focus entirely on the construction / formation of eco-social farms and which would operate in the form of associated groups that would be created on the basis of intergenerational solidarity. ${ }^{15}$ The project is tied to social entrepreneurship in rural areas and is similar to projects that were implemented in several European countries (Scotland, Finland, Greenland, North Ireland, and Sweden) known as O4O (Older People for Older People) that had positive results and additionally emphasized the potential for social entrepreneurship (Farmer et al., 2012). Even though for the time being the civil society organization is the only actor in this isolated case in Croatia which is trying to implement an idea similar to the aforementioned European project, it should be noted that the pilot project they prepared has prospects for connecting social entrepreneurship, intergenerational solidarity and rural development.

The pilot-project designed by the organization, which is based on social entrepreneurship, would operate in the following manner. It was already stated that Lika has preserved natural resources due to adverse modernization processes such as deruralization and deagrarization, and, as a consequence, the onset of negative demographic trends. These processes have led to an aging population, in particular during the past few decades. One of the consequences of aging is an increase in the number of farms whose owners, due to their old age, cannot cultivate the land, along with an increase in the number

15 As we already noted that Lika-Senj County has overall negative demographic trends, this also results in an elderly population and the absence of young people. Demographers have characterized Lika as an area with a "very elderly population" in which youth (0-19 years of age) account for only $18.7 \%$ of the population while those older than 60 account for $31 \%$ of the population (Nejašmić and Toskić, 2013). The implementation of the pilot project in question would mark the process of immigration of younger persons, who would in turn establish cooperation with farm owners. 
of abandoned farms. Therefore, the organization designed a pilot project that foresees cooperation between the farm owners incapable of farming and young people unable to become farm owners, due to social insecurity and precarity work, but who want to engage in farming, or are already so engaged, but on small, leased lots. The products of these farms would be organic, with intergenerational cooperation at the forefront. By pooling such farms, joint marketing and the return of investments to farms and local communities, social entrepreneurship would signify the beginning of the social change necessary for this rural area. It is not yet possible to present the designed end-project or its implementation, success and results. ${ }^{16}$ However, the available data on the project idea represents a shift in both the perception of complementary and alternative economic forms and in the enhancement of a particular possibility for striking a balance among the dimensions of sustainable development in the Lika area.

Table 3. Semi-structured group interview - the most prominent characteristics of the concept, attitudes regarding the status of social entrepreneurship at the national level and possibilities for the development of social entrepreneurship at the local level

\begin{tabular}{|l|l|}
\hline $\begin{array}{l}\text { Highlighted general characteristics of the } \\
\text { concept which interviewees believe play a key } \\
\text { role }\end{array}$ & $\begin{array}{l}\text { Innovativeness } \\
\text { Creation of social values } \\
\text { Enhancing social capital }\end{array}$ \\
\hline Status of social entrepreneurship & $\begin{array}{l}\text { At a lower level than other business entities } \\
\text { Civil society is the most important actor in } \\
\text { the development of social entrepreneurship } \\
\text { State and local government are not } \\
\text { contributing enough }\end{array}$ \\
\hline $\begin{array}{l}\text { Possibilities for the development of social } \\
\text { entrepreneurship in the Lika Region }\end{array}$ & $\begin{array}{l}\text { Agriculture: Eco-social farms } \\
\text { Grouping of farms } \\
\rightarrow \text { intergenerational solidarity }\end{array}$ \\
\hline $\begin{array}{l}\text { Current contribution of the organization in } \\
\text { the development of social entrepreneurship }\end{array}$ & $\begin{array}{l}\text { Project: "Eco-social development of the } \\
\text { Velebit area: Work in progress!": education } \\
\text { (innovativeness, social value, social capital) }\end{array}$ \\
\hline
\end{tabular}

\section{DISCUSSION}

\subsection{Social entrepreneurship as a supporting model for sustainable rural development: myth or reality?}

The research results indicate that social actors are aware of Lika's development potential, i.e. that developmental actors are aware of the potential for alternative and complementary economic forms that adapt to the concept of sustainable development in the local context. They see developmental prospects primarily in the preservation of natural

16 Due to the preparation of the project for a tender and in the interest of safeguarding project-related information, we cannot present the details withheld by the organization for these reasons. 
resources whose sustainable use creates the potential for economic development and improvement of the quality of life in local communities. Social actors see agriculture, in synergy with tourism and energy production from renewables, and complementariness rather than competition as the key to forming a more sustainable future.

Complementary and alternative economic forms, among which the interviewees also included "fairer distribution using new economic forms (e.g. social entrepreneurship)", have been denoted as factors that could lead to the improvement of the economy and general living conditions. They see social entrepreneurship as an economic model that would create a positive atmosphere for accepting other, more alternative models, since they are aware that a rural area is slower in accepting innovation compared to dynamic urban areas. Social entrepreneurship is also seen as a possibility for incorporating "the ideas of common people" in the economy, so that the latter adjusts to people, i.e. local communities. Having a civil society organization that educates local communities and works on preparing a specific project is an additional support for the future development of social entrepreneurship.

Given the points outlined above, how certain is it that social entrepreneurship will become a support model for sustainable development in Lika's rural area? Taking into consideration the fact that, both on the wider European and Croatian socio-entrepreneurship scene, this economic model assumed the role of meeting the needs of a primarily social and also environmental character, the model has prospects. The research interviewees recognized pragmatism, innovation and the specific vision by the actors as being characteristic in social entrepreneurship. Such features, in light of the results achieved so far, are also present with the members of the civil society organization that operates in Lika. In other words, actors willing to assume the planning and implementation of a sustainable development model tailored to the rural area do exist, they are also aware of the role of complementary and alternative economic models in enhancing the economic dimension of sustainable development in the rural area. On the other hand, despite an understanding of the developmental obstacles and opportunities for (sustainable) solutions to said obstacles, some of the key developmental actors assign the locus of control to external factors, thus refusing to assume responsibility for the development of the region in which they live. Thus, they transfer responsibility to either, in particular, administrative structures, or, ambiguously, to the lack of information and education, despite positive examples from the region. Social entrepreneurship can certainly be characterized as an economic model that supports sustainable development; however, for the time being, the development of social entrepreneurship in Lika depends on the efforts and success of a single organization and a small number of actors with a concrete vision.

\subsection{Balancing sustainable development via social entrepreneurship: the possibilities}

Finally, the question remains on how to strike a balance between the dimensions of sustainable development with the help of social entrepreneurship. Visible results can be achieved through a well-conceived and carefully planned combination of possibilities I potential of the rural area and developmental visions by local communities, together 
with already-existing institutional support at the regional (local action groups - LAGs), national (Ministry of Agriculture, Ministry of Regional Development and EU Funds, Ministry of Demography, Family, Youth and Social Policy), and, in particular, at the EU level (EU Regional Development Fund, European Agricultural Fund for Rural Development, European Social Fund). The end result would be a decrease in the developmental inequalities also observed in the territorial distribution of social entrepreneurship actors. It is necessary to empower communities so that they can create a desirable future on their own.

Since social entrepreneurship bears not only the entrepreneurial method but also environmental concerns and more democratic decision-making, it has the potential to influence the creation of local communities in the future. The research results indicate the need to form communities that co-create their own developmental models. Such communities, if they become a social reality in the Lika Region, i.e. if they are empowered through concrete measures (education, vocational retraining, expert consulting, agricultural grants, demographic measures, tax relief) could, according to the research results, assume the following roles: a) the role of local communities concerned for their environment (sustainable use of natural resources) by empowering family farms, alternative associations such as eco-social farms, energy production from renewables balancing the environmental dimension of sustainable development; b) the role of local communities that innovate to shape their own economic policies, primarily signifying cooperation and a joint operation on the market and a return on investment - balancing the economic dimension of sustainable development; c) the role of local communities open to social innovation that take intergenerational solidarity as their baseline balancing the socio-cultural dimension of sustainable development; d) the role of local communities that accept expertise that will enable utilization of the benefits of Croatia's EU membership - balancing the political dimension of sustainable development.

It is therefore obvious that balancing the dimensions, i.e. achieving the initial stage of sustainable development with the help of social entrepreneurship in the role of a support model needs to be launched by acting within local (rural) communities and their local area. Institutional support and an impulse that will launch activities at the local level and direct local actors is the foundation for shaping the bottom-up and top-down approach. It is clear that social activity and structures meet in this process.

\section{CONCLUSION}

Social entrepreneurship, at its core, means doing business based on the principles of social, environmental and economic sustainability. The profits or extra income earned is entirely or partially invested into the well-being of the community. A local community whose social reality is closely tied to a rural area and whose basic economic activity is tied to natural resources is forced to form its own activities in balance with the area's natural realities. It can, however, choose the way in which it will realize its own welfare or, simply stated, survival. 
"The economy need not be a necessary evil", as Lika's social actors conclude. In that context, they emphasized the need to adapt economic forms to a specific space, i.e. the real needs and developmental visions of individual local communities. Therefore, we can explain social entrepreneurship as a support model for sustainable development in a specific rural area and based on the vision of specific social actors, in the following manner. The interviewees see social entrepreneurship as a platform which, as confirmed in practice, provides for the creation of complementary and alternative economic forms adapted to the socioeconomic status of individual local communities. This is the first basis that denotes the importance of social entrepreneurship in Lika as a support model in the creation and implementation of the future sustainable development of the region. The second basis is found in the activities of the civil society organization in the rural area of Lika, which participates in its social reality by educating local communities of the possibilities offered by social entrepreneurship. It is also preparing a pilot project to implement social entrepreneurship in a specific space and provide actual members of the local community with an entrepreneurial venture. With the help of intergenerational solidarity and innovation as reference points, they will attempt to create new social values. The end product, eco-social farms, will mark the effort to preserve rural communities and the environment in the same proportion.

The third basis, as cited in this paper, is the "Strategy for the Development of Social Entrepreneurship" and it represents the national level of accepting an economic model that brings added value not necessarily expressed materially as profits. Even though additional regulations on social entrepreneurship are only now being prepared, the strategy as the basic national document marks an improvement.

Local developmental actors, civil society, a national strategy and certain benefits related to EU funds were indicated as being present, instituted, or prepared. It needs to be emphasized that some of the mostly rural Croatian counties (e.g. Lika-Senj) have not yet enacted the basic (regional) development strategy document - "Strategy of Regional Development of the Republic of Croatia for the period until 2020". The use of contemporary developmental concepts, such as sustainable and neo-endogenous development, would be more than useful in creating these strategies. The implementation of the concepts does not mean adopting them at a declarative level, but rather selecting the best and most suitable for the rural areas of Croatia or, in particular, the Lika Region, from the existing practices of developed areas. The concept of sustainable development would be used here as a guiding principle, while the neo-endogenous model would mark concrete and, in practice, applicable guidelines, pre-explored relations between entrepreneurship in general and the space in which it has been developed thus far. In that context, the concept of social entrepreneurship and its ability to modify and adjust enable the development of a concrete, local and thus original economic model.

This paper generally contributes to the considerations of social entrepreneurship that, by denoting a supporting economic model for sustainable development, emphasizes rural, often less developed areas. One such underdeveloped and, in a national context, often neglected area is the Lika Region. Therefore, the paper's practical value can be seen 
Soc. ekol. Zagreb, Vol. 27 (2018.), No. 1

A. Bušljeta Tonković et al: ...Sustainable Rural Development: A Case Study of Central Lika (Croatia)

in the actual discussion of the rural space and the ways in which contemporary developmental concepts can and should adapt to the area. A comprehensive and systematic survey on the topic should be conducted. The paper's scholarly contribution is based precisely on indicating the need for further research in both the model of social entrepreneurship tailored to the local context and to the overall economic models tailored to Croatia's rural areas. 


\section{REFERENCES}

Abercrombie, N., Hill, S. and Turner, B. S. (2008). Rječnik sociologije. Zagreb: Naklada Jesenski i Turk.

Akrap, A. and Gelo, J. (2009). Depopulacija Ličko-senjske županije tijekom 20. stoljeća s posebnim osvrtom na ekonomsko-socijalnu strukturu 1971.-2001. In: Holjevac, Ž. (ed.) Identitet Like - korijeni i razvitak (Knjiga II) (pp. 13-41). Zagreb: Institut društvenih znanosti Ivo Pilar.

Atterton, J., Newbery, R., Bosworth, G. and Affleck, A. (2011). Rural enterprise and neo- endogenous development. In: Alsos, G. A., Carter, S., Ljunggren E. and Welter, F. (eds.), The Handbook of Research on Entrepreneurship in Agriculture and Rural Development. Cheltenham UK: Edward Elgar Publishing Limited.

Bušljeta Tonković, A. (2015a). Održivi razvoj Središnje Like: Prinosi analizi ljudskog i socijalnog kapitala. Zagreb. Gospić: Institut društvenih znanosti Ivo Pilar i Državni arhiv u Gospiću.

Bušljeta Tonković, A. (2015b). Sociological Aspects of Sustainable Development Perspectives in Central Lika Through the Prism of Human and Social Capital. Sociologija i prostor, 53(2): 163-180.

Cifrić, I. (2003). Ruralni razvoj i modernizacija: prilozi istraživanju ruralnog identitet. Zagreb: Biblioteka znanost i društvo.

Chaves, R. and Monzón Campos, J. L. (2010). Socijalna ekonomija u europskoj uniji. Revija za socijalnu politiku, 17(1): 113-138.

Connelly, S., Markey, S. and Roseland, M. (2011). Bridging sustainability and the social economy: Achieving community transformation through local food initiatives. Critical Social Policy, 31(2): 308-324.

Croatian Bureau of Statistics (2011). Census of Population and Housing. URL: https:// www.dzs.hr (11 July 2017)

Defilipis, J. (1993). Upravljanje integralnim razvitkom ruralnih područja. Sociologija i prostor, 31(1-2): 35-39.

Drayton, W. (2002). The Citizen Sector: Becoming as Competitive and Entrepreneurial as Business. California Management Review, 44(3): 120-132.

Evans, P. (2001). Government Action, Social Capital, and Development: Reviewing the Evidence on Sinergy. In: Harris, J. M., Wise, T. A., Gallagher, K. P. and Goodwin, N. R. (eds.), A Survey of Sustainable Development: Social and Economic Dimensions (pp. 71-74). Somerville: The Global Development and Environment Institute Tufts University: Island Press.

Farmer, J., Hill, C. and Muñoz, S. A. (2012). Community Co-Production, Social Enterprise in Remote and Rural Communities. Cheltenham: Edward Elgar.

Fiamengo, A. (1987). Saint-Simone i Augste Comte. Zagreb: Naprijed.

Giddens, A. (1999). Treci put: obnova socijaldemokracije. Zagreb: Politička kultura.

Giddens, A. (2007). Sociologija. Zagreb: Nakladni zavod Globus. 
Geiger Zeman, M. and Zeman, Z. (2010). Uvod u sociologiju (održivih) zajednica. Zagreb: Institut društvenih znanosti Ivo Pilar.

Lay, V. (2007). Vizija održivog razvoja Hrvatske: prinosi artikulaciji polazišta i sadržaja vizije. In: Lay, V. (ed.), Razvoj sposoban za budućnost: prinosi promišljanju održivog razvoja Hrvatske (pp. 13-51). Zagreb: Institut društvenih znanosti Ivo Pilar.

Magaš, D. (2015). The Geography of Croatia. Zadar: University of Zadar.

Navarro, F. A., Woods, M. and Cejudo, E. (2016). The LEADER Initiative has been a Victim of Its Own Success. The Decline of the Bottom-Up Approach in Rural Development Programmes. The Case of Wales and Andalusia. Sociologia Ruralis, 56(2): 271-284.

Nejašmić, I. and Toskić, A. (2013). Starenje stanovništva u Hrvatskoj - sadašnje stanje i perspektive. Hrvatski geografski glasnik, 75(1): 89-100.

Nicholls, A. and Cho, A. H. (2006). Social Entrepreneurship: The structuration of the field. In: Nicholls, A. (ed.), Social Entrepreneurship - New Models of Sustainable Social Change (pp. 99-119). Oxford: Oxford University Press.

Pejnović, D. (2009). Geografske osnove identiteta Like. In: Holjevac, Ž. (ed.), Identitet Like - korijeni i razvitak (Knjiga I) (pp. 47-84). Zagreb: Zagreb: Institut društvenih znanosti Ivo Pilar.

Pokos, N. and Turk, I. (2013). Demografska obilježja naselja Gospić i Grada Gospića. In: Holjevac, Ž. (ed.), Gospić: grad, ljudi, identitet (pp. 13-41). Zagreb - Gospić: Institut društvenih znanosti Ivo Pilar.

Putnam, R. D. (2001). Bowling alone: The Collapse and Revival of American Community. New York: Simon and Schuster Paperbacks.

Ray, C. (2001). Culture Economies - a perspective on local rural development in Europe. Newcastle: Newcastle upon Tyne: Centre for rural economy.

Redclift, M. (1991). The Multiple Dimensions of Sustainable Development. Geography, 76(1): 36-42.

Ridley-Duff, R. and Bull, M. (2013). Understanding Social Enterprise - Theory and Practice. London: Sage Publications.

Rogić, V. (1977). Regionalizacija Gorske Hrvatske. Hrvatski geografski glasnik, 39(1): $25-43$. Sen, A. (1999). Development as freedom. New York: Oxford University Press.

Schmidt, C. (2004). The Analysis of Semi-structured Interviews. In: Flick, U., von Kardorf, E. and Steinke, I. (eds.), A Companion to Qualitative Research (pp. 253-258). London: Sage Publication.

Steinerowski, A. A. and Steinerowska-Streb, I. (2012). Can social enterprise contribute to creating sustainable rural communities? Using the lens of structuration theory to analyse the emergence of rural social enterprise. Local economy: The Journal of the Local Economy Policy Unit, 27(2): 167-182.

Steinerowski, A., Jack, S. and Farmer, J. (2008). Who are the social "entrepreneurs" and what do they actually do? Frontiers of the Entrepreneurship Research, 28(21): 1-16.

Ministry of Agriculture, Fishery and Rural Development (2008). Strategija ruralnog razvoja Republike Hrvatske za razdoblje 2008.-2013. godine. Zagreb: Ministry of 
Agriculture, Fishery and Rural Development. URL: http://www.azrri.hr/fileadmin/ dokumenti-download/STRATEGIJA_RR_2008-2013.pdf (20 September 2017)

Ministry of Labour and Pension System (2015). Strategija razvoja društvenog poduzetništva u Republici Hrvatskoj za razdoblje od 2015. do 2020. godine (2015). Zagreb: Ministry of Labour and Pension System. URL: http://www.esf.hr/wordpress/wp- content/uploads/2015/02/Strategija-razvoja-dru\%C5\%A1tvenog- poduzetni\%C5\%A1tva-u-RH-za-razdoblje-2015-2020.pdf (20 September 2017)

Šimleša, D., Bušljeta Tonković, A. and Puđak, J. (2016). Društveno poduzetništvo u Hrvatskoj: od prepoznavanja do primjene. Revija za sociologiju, 46(3): 271-295.

Šimleša, D., Puđak, J., Majetić, F. and Bušljeta Tonković, A. (2015a). Mapping New Horizons. Report on the state of social entrepreneurship in Croatia 2015. Zagreb: Institut društvenih znanosti Ivo Pilar.

Šimleša, D., Puđak, J., Majetić, F. and Bušljeta Tonković, A. (2015b). Across the Border - Social Economy in Europe. Zagreb: Institut društvenih znanosti Ivo Pilar.

Šundalić, A. (2010). Selo iz autenticnosti u neprepoznatljivost: prilog sociološkom istraživanju ruralnosti Slavonije i Baranje. Osijek: Sveučilište Josipa Jurja Strossmayera i Ekonomski fakultet u Osijeku.

Tolon-Becerra, A., Lastra-Bravo, X. and Galdeano-Gomez, E. (2010). Planning and neo- endogenous model for sustainable development in Spanish rural areas. International Journal of Sustainable Society, 2(2): 156-176.

United Nations General Assembly Economic and Social Council (2016). Mainstreaming of the three dimensions of sustainable development throughout the United Nations system. Report of the Secretary-General. URL: http://www.un.org/ga/search/view_doc.asp?symbol=A/71/76\&Lang=E (11 July 2017)

Volkmann, C. K., Tokarski, O. K. and Ernest, K. (2012). Background, Characteristics and Contest of Social Entrepreneurship. In: Volkmann, C. K., Tokarski, O. K. and Ernest, K. (eds.), Social Entrepreneurship and Social Business, An Introduction and Discussion with Case Studies (pp. 3-30). Springer Gabler.

Woods, M., (2012). Rural Development, Globalization and European Regional Policy: Perspectives from the DERREG Project. Geographia Polonica, 86(2): 99-109. 


\title{
DRUŠTVENO PODUZETNIŠTVO KAO POMOĆNI MODEL ODRŽIVOM RURALNOM RAZVOJU: STUDIJA SLUČAJA SREDIŠNJE LIKE (HRVATSKA)
}

\author{
Anita Bušljeta Tonković, Jelena Puđak i Dražen Šimleša
}

\begin{abstract}
Sažetak
Ovaj se rad bavi društvenim poduzetništvom kao pomoćnim modelom održivom ruralnom razvoju pomoću kojega bi se mogli uravnotežiti različiti razvojni aspekti Like. Teorijski dio rada istražuje veze izmecu neoendogenog i održivog razvoja. Rad je podijeljen u dva tematska dijela: u prvom dijelu rada predstavljeni su rezultati desk istraživanja postojećeg stanja društvenog poduzetništva u Hrvatskoj, dok su u drugom dijelu rada predstavljeni rezultati provedenog kvalitativnog istraživanja, u dvije etape. Prva etapa se sastojala od polu-strukturiranih intervjua s društvenim akterima uključenima u postojeći socio-ekonomski razvoj Like (2013), s time da je glavna tema istraživanja bila ekonomska dimenzija održivog razvoja. Druga etapa istraživanja sastojala se od polu-strukturiranih grupnih intervjua s onima koji prakticiraju druśtveno poduzetništvo u Lici (2015), prije svega organizacije civilnog društva, s time da je glavna tema istraživanja bila položaj i razvojna razina društvenog poduzetništva. Rezultati istraživanja ukazuju na osviještenost druśtvenih aktera o mogućnostima održivog razvoja u Lici (npr. očuvani prirodni resursi), kao i o postojanju alternativnih $i$ / ili komplementarnih ekonomskih modela koji bi mogli pomoci podizanju kvalitete života. Ključni društveni akteri (sudionici u istraživanju) vide društveno poduzetništvo kao priliku za razvijanje alternativnog / komplementarnog ekonomskog modela u Lici, primjerice "uklopiti ideje ljudi u ekonomiju i ekonomiju prilagoditi ljudima". Dodatni "poticajni" faktor za razvoj društvenog poduzetništva povezan je s akterima iz trećeg sektora, obzirom da rade na novom projektu koji kroz eko-socijalne farme pokušava na inovativan način udružiti poljoprivredna gospodarstva te tako jačati društveni kapital.
\end{abstract}

Ključne riječi: civilno društvo, lokalni društveni akteri, društveno poduzetništvo, održivi razvoj

\section{SOZIALUNTERNEHMERTUM ALS HILFSMODELL FÜR NACHHALTIGE LÄNDLICHE ENTWICKLUNG: FALLSTUDIE DES ZENTRALEN LIKA (KROATIEN)}

\author{
Anita Bušljeta Tonković, Jelena Puđak und Dražen Šimleša
}

\begin{abstract}
Zusammenfassung
Die vorliegende Arbeit befasst sich mit dem Sozialunternehmertum als Hilfsmodell für eine nachhaltige ländliche Entwicklung mit dessen Hilfe verschiedene Entwicklungsaspekte von Lika ausgeglichen werden können. Der theoretische Teil der Arbeit untersucht die Verbindung zwischen der nichtendogenen und der nachhaltigen Entwicklung. Die Arbeit ist thematisch in zwei Teile geteilt: Im ersten Teil der Arbeit sind die Ergebnisse der Sekundärforschung des jetzigen Zustands des Sozialunternehmertums in Kroatien dargestellt, während im zweiten Teil die Ergebnisse der in zwei Etappen durchgeführten qualitativen Forschung dargestellt sind. Die erste Etappe bestand aus halbstrukturierten Interviews mit den, in die bestehende sozioökonomische Entwicklung Likas eingeschlossenen sozialen Akteuren (2013), wobei das Hauptthema der Forschung die ökonomische Dimension der nachhaltigen Entwicklung war. Die zweite Etappe der Forschung bestand aus halbstrukturierten Gruppeninterviews mit denjenigen, die das Sozialunternehmertum in Lika praktizieren (2015), vor allem mit Organisationen der Zivilgesellschaft, wobei das Hauptthema der Forschung die Lage und die Entwicklungsebene des Sozialunternehmertums war. Die Forschungsergebnisse weisen auf das Bewusstsein der sozialen Akteure hinsichtlich der Möglichkeiten der nachhaltigen Entwicklung in Lika (z.B. erhaltene Naturressourcen), sowie auf das Bestehen von alterna-
\end{abstract}


Soc. ekol. Zagreb, Vol. 27 (2018.), No. 1

A. Bušljeta Tonković et al: ...Sustainable Rural Development: A Case Study of Central Lika (Croatia)

tiven bzw. komplementären ökonomischen Modelle hin, die zur Lebensqualität beitragen könnten. Die wichtigsten sozialen Akteure (Forschungsteilnehmer) sehen das Sozialunternehmertum als eine Chance zur Entwicklung eines alternativen bzw. komplementären ökonomischen Modells in Lika, beispielsweise "Die Ideen von Menschen kann man in die Ökonomie einschalten und die Ökonomie den Menschen anpassen". Ein zusätzlicher "Förderfaktor" für die Entwicklung des Sozialunternehmertums ist mit Akteuren aus dem Tertiärsektor verbunden, weil sie an einem neuen Projekt arbeiten, das durch öko-soziale Farmen auf eine innovative Art und Weise die landwirtschaftlichen Betriebe zu vereinen und somit das Gesellschaftskapital zu verstärken versuchen.

Schlüsselwörter: Zivilgesellschaft, lokale soziale Akteure, Sozialunternehmertum, nachhaltige Entwicklung 